\title{
Characterization of the promoter of human adipocyte hormone-sensitive lipase
}

\author{
Jacques GROBER ${ }^{\star}$, Henrik LAURELL $\uparrow$, Régis BLAISE*, Béatrice FABRY*, Stéphane SCHAAK*, Cecilia HOLM† \\ and Dominique LANGIN*1 \\ *Unité INSERM 317, Institut Louis Bugnard, Faculté de Médecine, Université Paul Sabatier, Bâtiment L3, CHU Rangueil, F-31403 Toulouse Cedex 4, France, and \\ $\dagger$ Section for Molecular Signalling, Department of Cell and Molecular Biology, Lund University, S-221 00 Lund, Sweden
}

\begin{abstract}
Hormone-sensitive lipase (HSL) catalyses the rate-limiting step of adipose tissue lipolysis. The human HSL gene is composed of nine exons encoding the adipocyte form and a testis-specific coding exon. Northern blot analyses showed that human adipocytes express a $2.8 \mathrm{~kb}$ HSL mRNA, suggesting the presence of a short $(20-150 \mathrm{bp}) 5^{\prime}$ untranslated region (5'-UTR). A single 5'UTR of approx. $70 \mathrm{nt}$ was detected in RNase $\mathrm{H}$ mapping experiments. Two 5'-UTRs of 70 and $170 \mathrm{nt}$ respectively were obtained by rapid amplification of cDNA ends and cDNA library screenings. RNase protection experiments, with probes derived from the two products, showed that human adipocyte HSL mRNA contains only the $70 \mathrm{nt}$ product. Primer extension analysis mapped the transcriptional start site $74 \mathrm{nt}$ upstream of the start codon. In HT29, a human cell line expressing HSL, the presence of the short or the long $5^{\prime}$-UTR is mutually exclusive.
\end{abstract}

The short and long 5'-UTR exons were located 1.5 and approx. $13 \mathrm{~kb}$ respectively upstream of the first coding exon. Various portions of the $5^{\prime}$-flanking region upstream of the short product exon were linked to the luciferase gene and transfected into cells that express HSL (HT29 cells and rat adipocytes) and do not express HSL (HeLa cells). High luciferase activity was found for constructs containing the sequence between $n t-2400$ and -86 , but not for shorter constructs. An analysis of $14 \mathrm{~kb}$ of genomic sequence revealed the presence of five DNase I hypersensitive sites associated with active gene transcription. Three of the sites are located in the vicinity of the transcriptional start site and could be linked to the minimal promoter activity. Two of the sites are located downstream of the exon containing the start codon, suggesting the presence of intronic regulatory elements.

\section{INTRODUCTION}

In mammals, hydrolysis of the triacylglycerol stored in adipose tissue is the major supply of energy through the release of free fatty acids into the plasma. The rate-limiting step of adipose tissue lipolysis is the hydrolysis of triacylglycerol into diacylglycerol by hormone-sensitive lipase (HSL). HSL is thus one of the enzymes determining whole-body fuel availability and it accounts for most of the detectable lipolysis in the post-absorptive state $[1,2]$. HSL is under acute neural and hormonal control. The enzyme is activated by catecholamines through cAMP-dependent phosphorylation, whereas insulin prevents this phosphorylation through the hydrolysis of cAMP.

As well as being expressed in adipose tissue, HSL is also expressed in steroidogenic tissues, mammary gland and muscle tissues [3-5]. Two isoforms of human HSL have been characterized. Human adipocytes express an $88 \mathrm{kDa}$ form, whereas human testes express a $120 \mathrm{kDa}$ form [5,6]. On comparison with rat HSL mRNA, a $3.3 \mathrm{~kb}$ human HSL mRNA was found in adipose tissue [7]. Subsequently, a long 5' untranslated region (5'-UTR) was characterized in human adipocytes [5]. We deduced from these results that the full-length human adipocyte HSL cDNA was $3250 \mathrm{nt}$ long. The $120 \mathrm{kDa}$ HSL protein in human testis is encoded by a $3.9 \mathrm{~kb}$ mRNA [6]. Analysis of coding sequences revealed that adipocyte and testis HSL are 775 and 1076 residues long respectively. The difference in size is due to a testis-specific N-terminal region. Elucidation of the HSL gene organization showed that nine coding exons are common to both forms $[5,6]$. The additional sequence in testis HSL is encoded by a $1.2 \mathrm{~kb}$ exon located $16 \mathrm{~kb}$ upstream of the first exon encoding the adipocyte form. The complex organization of the gene suggested the existence of several tissue-specific promoters.

The amount of HSL is considered to be the rate-limiting factor in adipocyte lipolysis. Any variation in HSL expression will therefore modulate the extent of adipose tissue lipid mobilization. Although acute regulation of HSL activity through reversible phosphorylation is well documented in adipose tissue, few studies have been devoted to variations in HSL expression in man. Recently, blunted HSL expression and low lipolytic capacity in adipose tissue was reported in normal-weight subjects with a family tendency to obesity and in patients with familial combined hyperlipidaemia [8,9]. Adaptation to a new physiological state can also modify HSL expression. Prolonged calorie restriction leads to an increase in adipocyte lipolysis and in HSL activity and protein levels [10]. Weight loss or calorie restriction causes a decrease in basal sympathetic activity $[11,12]$. A role for changes of sympathetic tone in the modulation of HSL expression was proposed [10]. This hypothesis is supported by the inhibitory action of cAMP on HSL gene expression observed in 3T3-F442A and BFC-1 adipocytes [13].

In view of the key role of HSL in energy metabolism and variations in HSL expression seen in physiological and pathological states, it is important to acquire detailed knowledge about the mechanisms regulating human HSL gene transcription. We

Abbreviations used: DMEM, Dulbecco's modified Eagle's medium; HSL, hormone-sensitive lipase; HSS, DNase I hypersensitive sites; RACE, rapid amplification of cDNA ends; 5'-UTR, 5' untranslated region.

1 To whom correspondence should be addressed. 
have investigated HSL expression in human adipocytes and a colon cancer cell line, HT29, that has been shown to express human HSL [14]. The size and relative abundance of HSL mRNA 5'-UTRs were determined by Northern blot analysis, RNase $\mathrm{H}$ mapping, RNase protection assay and various cDNA cloning protocols. Two novel exons corresponding to $5^{\prime}$-UTRs were characterized. The adipocyte-specific transcriptional start site was mapped by primer extension analysis, and the promoter activity was analysed in HT29 cells, rat adipocytes and HeLa cells by using a sensitive reporter gene assay. Finally, DNase I hypersensitive sites (HSS) associated with active gene transcription were mapped in the human HSL gene.

\section{MATERIALS AND METHODS}

\section{RNA preparation}

Total RNA was prepared from isolated human adipocytes or HT29 cells by using a single-step guanidium thiocyanate/ phenol/chloroform extraction [15]. Poly $(\mathrm{A})^{+}$RNA was prepared from total RNA with a Dynabeads mRNA purification kit (Dynal). Briefly, $100 \mu \mathrm{g}$ of total RNA was heated at $65^{\circ} \mathrm{C}$ for 5 min, hybridized to $(\mathrm{dT})_{25}$-linked magnetic beads at room temperature for $10 \mathrm{~min}$, cleaned twice with washing solution [10 mM Tris $/ \mathrm{HCl}(\mathrm{pH} \mathrm{7.5)/0.15} \mathrm{M} \mathrm{LiCl/1} \mathrm{mM} \mathrm{EDTA]} \mathrm{and}$ eluted with $20 \mu \mathrm{l}$ of $2 \mathrm{mM}$ EDTA at $65^{\circ} \mathrm{C}$. Poly(A) ${ }^{+}$RNA was used immediately.

\section{Northern blot analyses}

Human adipocyte total RNA and poly(A) ${ }^{+}$RNA, RNA transcribed in vitro from human HSL cDNA (2888 and $2660 \mathrm{bp}$ ) and RNA size markers obtained by transcription in vitro of different fragments of $\lambda$ DNA (Promega) were electrophoresed in a $1 \%$ $(\mathrm{w} / \mathrm{v})$ agarose $/ 2.2 \mathrm{M}$ formaldehyde gel, transferred to nylon membrane (Hybond N; Amersham) and cross-linked with UV [16]. The blots were hybridized for $16 \mathrm{~h}$ at $65^{\circ} \mathrm{C}$ in $0.5 \mathrm{M}$ $\mathrm{Na}_{2} \mathrm{HPO}_{4} / 1 \mathrm{mM}$ EDTA $/ 7 \%$ (w/v) SDS $/ 1 \%$ (w/v) BSA with a 585 bp human HSL cDNA probe (nt 101-685 downstream of ATG) generated by PCR with the oligonucleotide 5'-AGGCGTTTTTGCCGGTGTAC-3' as the sense primer and 5'TGTGATCCGCTCAAACTCAG- $3^{\prime}$ as the anti-sense primer. RNA size markers were hybridized with ${ }^{32} \mathrm{P}$-labelled $\lambda$ DNA/ HindIII fragments. Blots were washed at a final stringency of $15 \mathrm{mM} \mathrm{NaCl} / 1.5 \mathrm{mM}$ citric acid $/ 0.1 \%$ SDS at $65^{\circ} \mathrm{C}$ and subjected to digital imaging (Molecular Dynamics).

\section{RNase H mapping}

Human adipocyte total RNA $(30 \mu \mathrm{g})$ was freeze-dried and resuspended in $10 \mu \mathrm{l}$ of RNase $\mathrm{H}$ buffer $[20 \mathrm{mM}$ Tris $/ \mathrm{HCl}$ (pH 7.5)/10 mM $\mathrm{MgCl}_{2} / 100 \mathrm{mM} \mathrm{KCl} / 0.1 \mathrm{mM}$ dithiothreitol/ $5 \%(\mathrm{w} / \mathrm{v})$ sucrose] containing $10 \mathrm{pmol}$ of the single-stranded anti-sense oligonucleotide 5'-GTACACCGGCAAAAACGCCTGACAG-3' (nt 120-96 downstream of ATG). After 10 min at $70{ }^{\circ} \mathrm{C}$, hybridization was performed for $30 \mathrm{~min}$ at $37^{\circ} \mathrm{C}$. Then $40 \mu \mathrm{l}$ of RNase $\mathrm{H}$ buffer containing 7 units of RNase $\mathrm{H}$ (Amersham) were added and digestion was performed for $45 \mathrm{~min}$ [17]. After precipitation with ethanol, the digestion products were separated on a polyacrylamide/urea gel. The gel was washed twice in $7 \%(\mathrm{v} / \mathrm{v})$ formaldehyde $/ 9 \mathrm{mM}$ Tris/borate/ $0.2 \mathrm{mM}$ EDTA and RNA was passively transferred to a nylon membrane. Hybridization was performed as described above with ${ }^{32}$ P-labelled oligonucleotide (nt 63-38 downstream of ATG) and cDNA probe (the most 5' $50 \mathrm{nt}$ of product B; see below).

\section{cDNA library screening}

Two human fat-cell cDNA libraries (Clontech) were screened with the ${ }^{32} \mathrm{P}$-labelled 585 bp human HSL cDNA probe. Hybridization was performed under standard conditions $[5,16]$. Stringent washes were performed at $60^{\circ} \mathrm{C}$ in $30 \mathrm{mM} \mathrm{NaCl} / 3 \mathrm{mM}$ citric acid $/ 0.1 \%$ SDS. Positive clones were subcloned into pBluescript KS (Stratagene) and sequenced by dideoxy sequencing.

\section{Rapid amplification of cDNA ends (RACE)}

The Marathon RACE kit (Clontech) was used to amplify the 5 ' ends of human HSL cDNA species in accordance with the manufacturer's protocol. Briefly, $500 \mathrm{ng}$ of poly $(\mathrm{A})^{+}$RNA from human adipocytes and HT29 cells were reverse-transcribed with oligo(dT). After synthesis of the complementary strand, a modified anchor primer was ligated to the $5^{\prime}$ end of the doublestranded cDNA with T4 DNA ligase. Amplification of the $5^{\prime}$ ends was performed with a sense primer derived from the anchor primer and a gene-specific anti-sense primer (nt 120-96 downstream of ATG). RACE products were subcloned into pBluescript KS and sequenced by dideoxy sequencing.

\section{RNase protection assay}

Two RACE products were used as probes. Probes A and B contained 170 and $70 \mathrm{bp}$ respectively of the 5' UTR. Anti-sense RNA species produced with T7 RNA polymerase for probe A and T3 RNA polymerase for probe B were labelled by incorporating $\left[{ }^{32} \mathrm{P}\right] \mathrm{UTP}$ into the reaction mixture [18]. The DNA template was eliminated by RQ1 DNase (Promega) digestion for 15 min at $37^{\circ} \mathrm{C}$. The quality and integrity of labelled probes were checked on a $5 \%(\mathrm{w} / \mathrm{v})$ polyacrylamide/7 M urea gel. Hybridizations were performed by mixing the labelled cRNA probe in $30 \mu 1$ of hybridization buffer $[80 \%$ deionized formamide $/ 0.4 \mathrm{M}$ $\mathrm{NaCl} / 1 \mathrm{mM}$ EDTA/40 mM Pipes (pH 6.7)] with the appropriate RNA (30 $\mu \mathrm{g}$ of human adipocyte RNA or $200 \mu \mathrm{g}$ of HT29 RNA). The mixture was heated to $95^{\circ} \mathrm{C}$ for $5 \mathrm{~min}$ and transferred immediately to a $55^{\circ} \mathrm{C}$ heating block for $14-18 \mathrm{~h}$. Thereafter $0.3 \mathrm{ml}$ of $300 \mathrm{mM} \mathrm{NaCl} / 5 \mathrm{mM}$ EDTA/10 mM Tris/HCl $(\mathrm{pH}$ 7.5) containing $20 \mu \mathrm{g}$ of RNase A and $1 \mu \mathrm{g}$ of RNase T1 were added. After $1 \mathrm{~h}$ at $37^{\circ} \mathrm{C}$, digestion was stopped by the addition of $50 \mu \mathrm{g}$ of proteinase $\mathrm{K}$, and the samples were incubated for a further $15 \mathrm{~min}$ at $37^{\circ} \mathrm{C}$. Guanidinium thiocyanate (4 M, 1 vol.)/ $25 \mathrm{mM}$ sodium acetate $(\mathrm{pH} 7) / 0.5 \%$ sarcosyl $/ 0.1 \mathrm{M} \beta$-mercaptoethanol and $10 \mu \mathrm{g}$ of yeast tRNA were added, followed by precipitation with propan-2-ol. The RNA pellets were washed with $70 \%(\mathrm{v} / \mathrm{v})$ ethanol, dried, dissolved in $10 \mu \mathrm{l}$ of sample buffer $[97 \%(\mathrm{v} / \mathrm{v})$ deionized formamide $/ 0.1 \%$ SDS $/ 10 \mathrm{mM}$ Tris $/ \mathrm{HCl}(\mathrm{pH} 7.0)]$, and loaded on a $5 \%(\mathrm{w} / \mathrm{v})$ polyacrylamide/7 M urea gel. The gel was analysed by digital imaging (Molecular Dynamics).

\section{Primer extension analysis}

A 24-mer oligonucleotide 5'-CTCCTAGGCATCTTCCGAGCTTCC-3' complementary to nt $29-42$ in exon B (see the Results section) was labelled at the $5^{\prime}$ end with $\left[\gamma^{-32} \mathrm{P}\right]$ ATP and T4 polynucleotide kinase. The ${ }^{32} \mathrm{P}$-labelled primer was hybridized with $500 \mathrm{ng}$ of human adipocyte poly(A) ${ }^{+}$RNA in $150 \mathrm{mM}$ $\mathrm{KCl} / 10 \mathrm{mM}$ Tris $/ \mathrm{HCl}(\mathrm{pH} 8.3) / 1 \mathrm{mM}$ EDTA for $90 \mathrm{~min}$ at $65^{\circ} \mathrm{C}$ and cooled slowly to room temperature [16]. The hybridized primer-RNA complex was extended in a $45 \mu \mathrm{l}$ volume containing $20 \mathrm{mM}$ Tris/ $\mathrm{HCl}, \mathrm{pH} 8.3,10 \mathrm{mM} \mathrm{MgCl}, 5.5 \mathrm{mM}$ dithiothreitol, $0.15 \mathrm{mM}$ dNTP, 50 units of RNase inhibitor (RNA Guard; Pharmacia) and 200 units of reverse transcriptase (Superscript II; Gibco-BRL) for $90 \mathrm{~min}$ at $42{ }^{\circ} \mathrm{C}$. The reaction was stopped 
by adding $105 \mu \mathrm{l}$ of RNase mix (10 mM Tris/HCl $(\mathrm{pH} 7.5) / 1 \mathrm{mM}$ EDTA $/ 100 \mathrm{mM} \mathrm{NaCl}$ containing $20 \mu \mathrm{g} / \mathrm{ml}$ RNase A and $100 \mu \mathrm{g} / \mathrm{ml}$ salmon sperm DNA) for $15 \mathrm{~min}$ at $37^{\circ} \mathrm{C}$. After extraction with phenol/chloroform ( $\mathrm{v} / \mathrm{v})$ and precipitation with ethanol, the extension products were separated on a $6 \%(\mathrm{w} / \mathrm{v})$ polyacrylamide $/ 8 \mathrm{M}$ urea sequencing gel and detected by autoradiography. The corresponding HSL genomic fragment was sequenced with the same primer and run in parallel.

\section{Plasmid constructions, cell transfection and luciferase analyses}

A $2.6 \mathrm{~kb}$ DNA genomic fragment containing the transcription start site was subcloned and used as a template in the PCR-based generation of different deletions of the promoter region. PCR reactions were performed with a proof-reading DNA polymerase ( $P f u$ DNA polymerase; Stratagene) and a common anti-sense primer that ended $38 \mathrm{bp}$ downstream of the transcription start site. Nine fragments $(-2400,-1000,-431,-367,-290$, $-187,-86,-57$ and $-31 \mathrm{bp}$ ) were cloned in a sense orientation upstream of the firefly luciferase-coding gene into the pGL3basic vector (Promega). Two fragments $(+1000$ and $+431 \mathrm{bp})$ were cloned in the anti-sense orientation. Transfections into HT29 cells were performed with cationic lipids (TFX-50; Promega) and $2 \mu \mathrm{g}$ of each construct in $1.9 \mathrm{~cm}^{2}$ plates. Transfection efficiencies were normalized by co-transfecting the different constructs with $20 \mathrm{ng}$ of pRL-CMV vector containing the cDNA encoding Renilia luciferase (Promega). HeLa cells in $9.4 \mathrm{~cm}^{2}$ plates were transfected with lipofectin (Gibco-BRL) plus $2 \mu \mathrm{g}$ of each construct and $100 \mathrm{ng}$ of pRL-CMV vector. HT29 and HeLa cells were harvested $48 \mathrm{~h}$ after transfection for the determination of luciferase activity. Isolated rat adipocytes were prepared by collagenase digestion of epididymal fat pads [18]. Cells were washed three times in Dulbecco's modified Eagle's medium (DMEM). Packed cells $(0.2 \mathrm{ml})$ supplemented with $0.2 \mathrm{ml}$ of DMEM were distributed in electroporation cuvettes with a $0.4 \mathrm{~cm}$ gap (Eurogentec) containing $20 \mu \mathrm{g}$ of each construct and $1 \mu \mathrm{g}$ of pRL-CMV vector. After preliminary experiments to determine optimal transfection conditions, adipocyte electroporation [19] was performed at $200 \mathrm{~V}$ and $900 \mu \mathrm{F}$ (Cellject; Eurogentec). Cells were immediately transferred to $5 \mathrm{ml}$ tubes containing $1.5 \mathrm{ml}$ of DMEM supplemented with $10 \%$ (v/v) fetal calf serum (Gibco-BRL) and incubated at $37^{\circ} \mathrm{C}$ for $24 \mathrm{~h}$. Firefly and Renilia luciferase activities were measured with the DualLuciferase Reporter Assay System (Promega) and a luminometer (Luminoskan; Labsystem).

\section{Nuclei preparation and digestion with DNase I}

Nuclei preparation was done by the method of Richard-Foy and Hager [20], with modifications. HT29 and Caco2 cells were grown in DMEM supplemented with $5 \%(\mathrm{v} / \mathrm{v})$ fetal calf serum (HT29) or $10 \%$ (v/v) fetal calf serum (Caco2). Cells were grown to confluence, washed with PBS, scraped with a rubber 'policeman' in PBS and centrifuged for $5 \mathrm{~min}$ at $1700 \mathrm{~g}$ at $4{ }^{\circ} \mathrm{C}$. The cell pellet was resuspended in homogenization buffer $[10 \mathrm{mM}$ Tris/ $\mathrm{HCl}(\mathrm{pH} 7.4) / 15 \mathrm{mM} \mathrm{NaCl} / 60 \mathrm{mM} \mathrm{KCl} / 0.15 \mathrm{mM}$ spermine $/ 0.5 \mathrm{mM}$ spermidine $/ 1 \mathrm{mM}$ EDTA $/ 0.1 \mathrm{mM}$ EGTA $/ 0.2 \%$ Nonidet P40/5\%(w/v) sucrose] and homogenized in a Dounce homogenizer (ten strokes with pestle A). The homogenate was centrifuged for $20 \mathrm{~min}$ at $1600 \mathrm{~g}$ through a $10 \%$ (w/v) sucrose cushion in homogenization buffer. The pellets were resuspended in washing buffer $[10 \mathrm{mM}$ Tris $/ \mathrm{HCl}(\mathrm{pH} 7.4) / 15 \mathrm{mM} \mathrm{NaCl} /$ $60 \mathrm{mM} \mathrm{KCl} / 0.15 \mathrm{mM}$ spermine $/ 0.5 \mathrm{mM}$ spermidine], pelleted again and pooled in $3 \mathrm{ml}$ of washing buffer. The amount of DNA in the nuclear suspension was estimated by measuring the absorbance at $260 \mathrm{~nm}$ of a fraction of the nuclear suspension lysed in $1 \%(\mathrm{w} / \mathrm{v})$ SDS. The integrity of nuclei was checked by Trypan Blue coloration. The cold nuclear suspension was divided into $1 \mathrm{ml}$ fractions, adjusted with $10 \mu \mathrm{l}$ of $50 \mathrm{mM} \mathrm{CaCl}_{2}$ and $20 \mu \mathrm{l}$ of $50 \mathrm{mM} \mathrm{MgCl}{ }_{2}$. The reaction was initiated by additions of various amounts of $1 \mathrm{mg} / \mathrm{ml}$ bovine pancreatic DNase I (approx. 2000 units/mg; Worthington). The tubes were incubated for $10 \mathrm{~min}$ at $20^{\circ} \mathrm{C}$. The reaction was stopped by addition of $1 \mathrm{ml}$ of stop buffer [ $25 \mathrm{mM}$ EDTA $/ 2 \%$ (w/v) SDS $/ 200 \mu \mathrm{g} / \mathrm{ml}$ proteinase $\mathrm{K}$ ] and incubated overnight at $37^{\circ} \mathrm{C}$. The samples were first extracted with phenol, then with phenol/chloroform/3methylbutan-1-ol (25:24:1, by vol.) and finally three times with chloroform/3-methylbutan-1-ol $(24: 1, \mathrm{v} / \mathrm{v})$ and precipitated with ethanol. Pellets were resuspended in $10 \mathrm{mM}$ Tris $/ \mathrm{HCl}$ $(\mathrm{pH} 7.4) / 2.5 \mathrm{mM}$ EDTA. For each DNase I digestion point, $40 \mu \mathrm{g}$ of purified DNA was digested to completion with EcoRI or XhoI (5 units $/ \mu \mathrm{g}$ of DNA). Samples were precipitated in the presence of 0.01 vol. of tRNA $(10 \mathrm{mg} / \mathrm{ml})$, resuspended in $10 \mathrm{mM}$ Tris/ $\mathrm{HCl}(\mathrm{pH} \mathrm{7.4)} / 1 \mathrm{mM}$ EDTA, and electrophoresed on a $0.8 \%$ agarose gel for $12-16 \mathrm{~h}$. The DNA was transferred passively to nylon membrane (Hybond N; Amersham). Probes (20-30 ng) were labelled with $\left[{ }^{32} \mathrm{P}\right] \mathrm{dCTP}(3000 \mathrm{Ci} / \mathrm{mmol})$ with the use of a random priming kit (Pharmacia). Hybridization was performed under standard conditions [16]. Blots were washed at a final stringency of $30 \mathrm{mM} \mathrm{NaCl} / 3 \mathrm{mM}$ citric acid/0.1\% SDS. Blots were autoradiographed for 2-7 days.

\section{RESULTS}

\section{Size of HSL mRNA and $5^{\prime}$ non-coding region}

Precise analysis of human adipocyte total and poly(A) ${ }^{+}$RNA showed that the size of human HSL mRNA was between 2.75 and $2.8 \mathrm{~kb}$ (Figure 1) and not $3.3 \mathrm{~kb}$ as previously reported [7]. This result consequently indicates that the $5^{\prime}$-UTR(s) are much shorter (between 20 and $150 \mathrm{bp}$ assuming a poly(A) tail between 50 and $150 \mathrm{nt})$ than initially reported (632 nt) [5].

To determine accurately the number and length of 5'-UTR(s), we developed an RNase $\mathrm{H}$ mapping test. Adipocyte total RNA

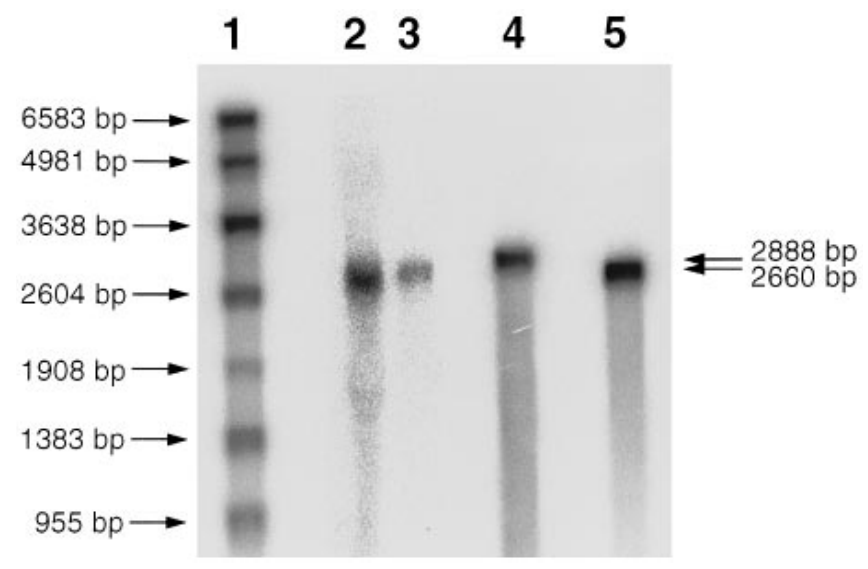

Figure 1 Northern blot analysis of human HSL mRNA size in adipocytes

Total and poly $(A)^{+}$RNA were prepared from isolated human adipocytes as described in the Materials and methods section. RNA size markers (500 ng) (lane 1), $30 \mu \mathrm{g}$ of adipocyte total RNA (lane 2), $250 \mathrm{ng}$ of adipocyte poly $(\mathrm{A})^{+}$RNA (lane 3), 2888 bp human HSL RNA transcribed in vitro (lane 4) and 2660 bp human HSL RNA transcribed in vitro (lane 5) were electrophoresed on a $1 \%(\mathrm{w} / \mathrm{v})$ agarose/2.2 $\mathrm{M}$ formaldehyde gel and transferred to nylon membrane. The blot was hybridized with ${ }^{32}$ P-labelled HSL CDNA and $\lambda$ DNA/HindIII probes. The digital picture is representative of three independent experiments that gave similar results. 


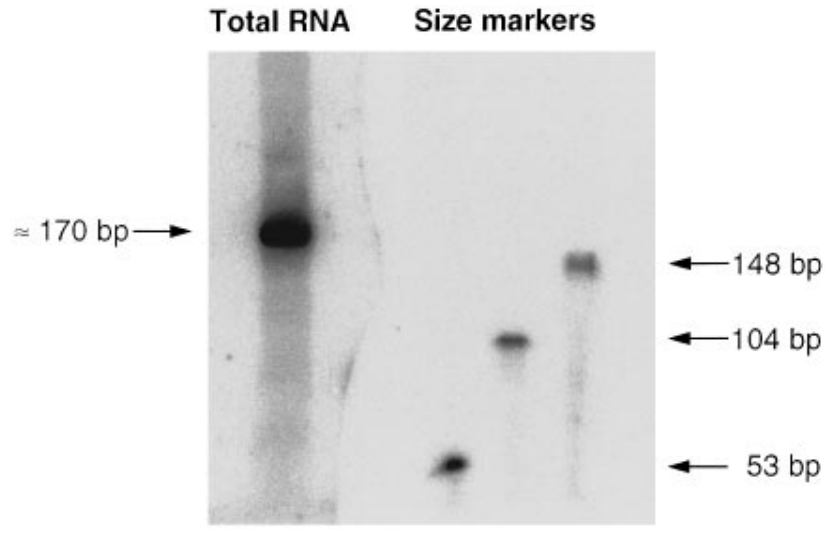

Figure 2 RNase H mapping analysis of human HSL mRNA 5'-UTR

Adipocyte total RNA $(30 \mu \mathrm{g})$ was digested by RNase $\mathrm{H}$ as described in the Materials and methods section, then denatured and electrophoresed on a polyacrylamide/urea gel. The blot was hybridized with a ${ }^{32}$-labelled oligonucleotide located in the coding sequence (nt 63-38 downstream of ATG). RNA size markers were produced by transcription in vitro and labelled by including ${ }^{32}$ P]UTP in the reaction mixture. The digital picture is representative of five independent experiments that gave similar results.

was annealed to a single-stranded oligonucleotide located in the coding region of human HSL from nt 120-96. RNA hybridized to DNA was digested with RNase $\mathrm{H}$ and the products of digestion were electrophoresed in a denaturing polyacrylamide gel. After blotting, the 5'-fragment(s) of the HSL mRNAs were revealed by hybridization to a labelled oligonucleotide located in the coding region between nt 63 and 38. A single band was detected, showing the presence of a single major $5^{\prime}$-UTR in the HSL mRNA of human adipocytes (Figure 2). The $5^{\prime}$-UTR was approx. $70 \mathrm{bp}$ long, which is in agreement with results from Northern blot analysis.

\section{Cloning of $5^{\prime}$ non-coding regions}

Two independent strategies were used to clone the $5^{\prime}$ non-coding regions of HSL transcripts in human adipocytes and HT29, the only human cell line known to express an HSL protein similar in size to the adipocyte isoform [14]. 5'-RACE experiments were performed on poly(A) ${ }^{+}$RNA from human adipocytes and HT29 cells. Two major products, named $\mathrm{A}$ and $\mathrm{B}$, were cloned and sequenced. The $\mathrm{A}$ and $\mathrm{B}$ sequences did not correspond to the sequence of the previously published $5^{\prime}$-UTR [5]. In adipocytes, many more clones (more than $80 \%$ ) corresponding to the $\mathrm{B}$ product than to the A product were obtained. A and B contained 170 and $70 \mathrm{bp}$ respectively of 5'-UTRs. The $20 \mathrm{nt}$ immediately upstream of the start codon were common to the two products. In one RACE experiment, a single PCR product corresponding to the $5^{\prime}$ end of the previously reported $5^{\prime}$-UTR [5] was obtained. This result indicated that HSL mRNA species with a 5'-UTR more than $600 \mathrm{nt}$ long, corresponding to a genomic sequence contiguous to exon 1, are rare in human adipocytes. Accordingly no hybridization was seen in Northern blot experiments containing human adipocyte total RNA with a probe derived from that region (nt 128-502 of the ATG) (results not shown). Two human adipose tissue cDNA libraries were screened with a cDNA probe (nt 101-593 downstream of ATG). The clones containing 5'-UTRs were sequenced. They corresponded to products A and B. Again, B was the more abundant product.

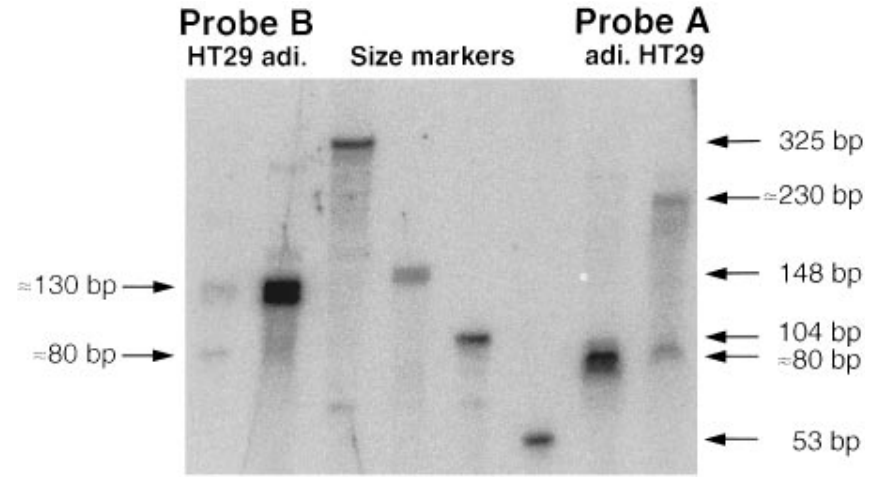

Figure 3 Abundance of $5^{\prime}$-UTRs in human HSL transcripts determined by RNase protection assay

RACE products $A$ and $B$ were used as cRNA probes (see the Results section). Uniformly ${ }^{32} \mathrm{P}$ labelled probes were hybridized with $30 \mu \mathrm{g}$ of adipocyte (adi.) total RNA and $200 \mu \mathrm{g}$ of HT29 cell total RNA. Samples were digested with a mixture of RNase A and RNase T1, and resistant hybrids were analysed by electrophoresis on a polyacrylamide/urea gel. RNA size markers were produced by transcription in vitro and labelled by including [ $\left.{ }^{32} \mathrm{P}\right]$ UTP in the reaction mixture. The digital picture is representative of four independent experiments that gave similar results.

\section{Abundance of the $\mathbf{5}^{\prime}$ non-coding regions in HSL transcripts}

Because RACE and library screening are not quantitative methods, the respective abundance of $5^{\prime}$-UTRs in HSL transcripts was determined with an RNase protection assay. Products A and B were used as cRNA probes on adipocyte and HT29 cell total RNA (Figure 3). In adipocytes, resistant hybrids were $80 \mathrm{bp}$ (probe A) and $130 \mathrm{bp}$ (probe B). The hybrid obtained with probe A corresponded to the protection of $63 \mathrm{nt}$ of coding region and $20 \mathrm{nt}$ of the $5^{\prime}$-UTR immediately upstream of the start codon, indicating that the $5^{\prime}$-UTR specific to probe A was not present in significant amounts in adipocytes. Probe B, in contrast, was entirely protected. These results show that the $5^{\prime}$-UTR specific to probe $\mathrm{B}$ is the major $5^{\prime}$-UTR in human adipocyte HSL transcripts. The presence of a second band of slightly shorter size than the approx. $130 \mathrm{bp}$ band (Figure 3) was observed in two of four experiments. This resistant hybrid might result from the formation of an intramolecular loop at one edge of the cRNA probe that precludes hybridization with the entire target mRNA. The RNase protection assay results were confirmed in RNase $\mathrm{H}$ mapping experiments. A single band corresponding to a $5^{\prime}$-UTR of approx. $70 \mathrm{bp}$ was detected by using the most 5' $50 \mathrm{nt}$ of product $\mathrm{B}$ as a probe. When product A-specific sequence was used as a probe, no signal was detected (results not shown). In HT29 cells, RNase protection assay showed that protected products were 230 and $80 \mathrm{bp}$ with probe $\mathrm{A}$, and 130 and $80 \mathrm{bp}$ with probe $\mathrm{B}$. The $80 \mathrm{bp}$ resistant hybrid corresponded to $63 \mathrm{nt}$ of coding region and $20 \mathrm{nt}$ of $5^{\prime}$-UTR as described above for adipocytes. The 230 and $130 \mathrm{bp}$ bands corresponded to the protection of product A- and product B-specific 5'-UTRs respectively. These results show the presence of two types of HSL transcript in HT29 cells containing either product A- or product B-specific 5'-UTRs. These 5'-UTRs were mutually exclusive because only two protected bands were observed (Figure 3).

\section{Genomic localization of two novel exons}

Four cosmids containing overlapping DNA sequences, which have been mapped to chromosome 19centq13.1-13.2 and shown 


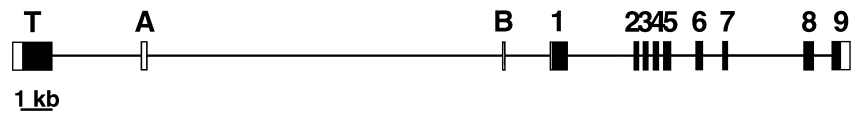

Figure 4 Organization of the human HSL gene

Coding sequences are shown as filled boxes and UTRs as open boxes. Exon $\mathrm{T}$ is the testisspecific exon; the newly characterized exons are exons $A$ and $B$.

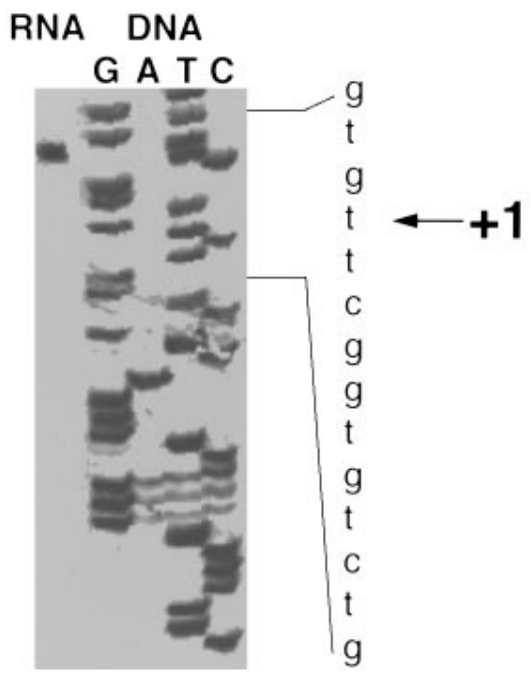

Figure 5 Determination of the human HSL gene transcriptional start site with the use of primer extension analysis

A 24-mer oligonucleotide complementary to RACE product B-specific $5^{\prime}$-UTR was ${ }^{32}$ P-labelled and hybridized to $500 \mathrm{ng}$ adipocyte poly $(A)^{+}$RNA. Reverse transcription was performed as described in the Materials and methods section. Genomic sequencing was performed with the same 24-mer oligonucleotide. The extension and sequencing products were separated on a $6 \%$ (w/v) polyacrylamide/8 M urea gel. The autoradiogram is representative of two independent experiments that gave similar results.

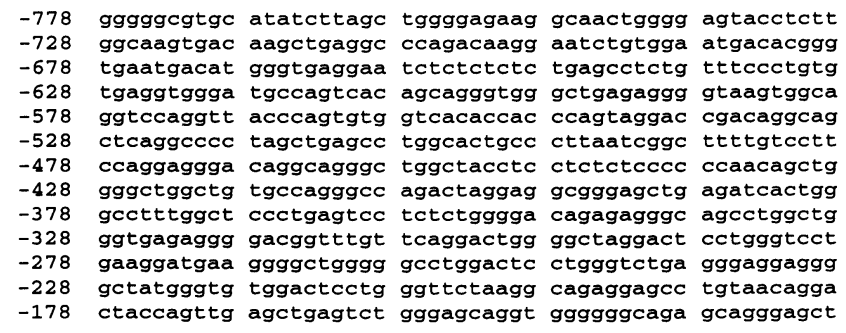$$
\text { CAC }
$$

-128 gagccetcta ctctgtttac agcacgtggt cctcactgat ctttctgggt

$$
\text { box GC box }
$$

-78 $\overline{\text { gggaggtggc ttgtgegget acaccctggg caggccagec ccgcccecgg }}$ $\mathrm{A}+\mathrm{T}$ rich

-28 gtttattgcc ccaggctgct actggcacAA GCCACAGACC AGCAGTCCCA +23 GCCCAGGGAA GCTCGGAAGA TGCCTAGGAG GGgtgagtgt cc--intron (1508 bp) - acctgcccac agCCTCAAGG CTCATCCACA ACATGGACCT

\section{Figure 6 Genomic sequence of the region containing exon B}

Lower-case letters indicate promoter and intronic sequences; capital letters show exonic sequences. The transcriptional start site is indicated as +1 . The GT/AG consensus sequences for splice junctions are underlined. Putative transcription factor binding sites are overlined. The start codon for the adipocyte form of human HSL is shown in italics.

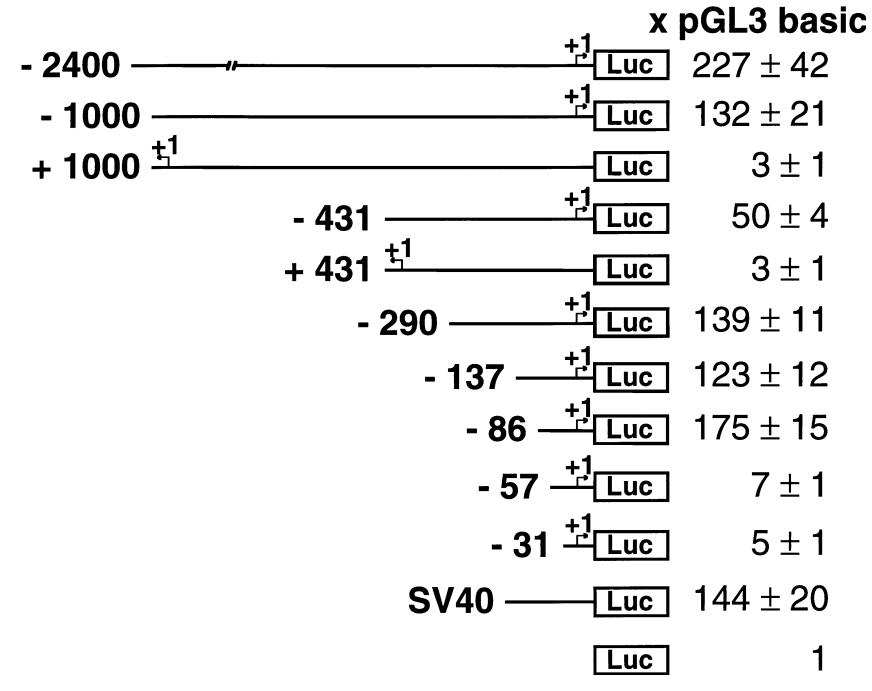

Figure 7 Deletion analysis of human HSL promoter activity in HT29 cells

HT29 cells were transiently transfected with HSL promoter-luciferase gene fusion constructs and pRL-CMV as control of transfection efficiency, as described in the Materials and methods section. The data are means \pm S.E.M. for nine experiments. Activities are normalized for transfection efficiency and expressed relative to the activity of the promoterless PGL3 basic vector. HSL promoter activities were compared with the activity of the viral promoter SV40. The transcriptional start site is indicated as +1 .

Table 1 Deletion analyses of human HSL promoter activity in rat adipocytes and HeLa cells

Rat adipocytes and HeLa cells were transiently transfected with HSL promoter-luciferase gene fusion constructs and pRL-CMV as control of transfection efficiency as described in the Materials and methods section. $5^{\prime}$-Flanking regions of various lengths were generated by PCR with sense primers located at various distances from the transcriptional start site and a common anti-sense primer located at +38 . The data are means \pm S.E.M. for three independent experiments performed in duplicate. Activities are normalized for transfection efficiency and expressed relative to the activity of the promoterless pGL3 basic vector. HSL promoter activities were compared with the activity of the viral promoter SV40.

\begin{tabular}{ccc}
\hline Construct & Rat adipocytes & HeLa cells \\
\hline-2400 & $36 \pm 6$ & $54 \pm 4$ \\
-1000 & $63 \pm 15$ & $79 \pm 3$ \\
-431 & $50 \pm 10$ & $68 \pm 9$ \\
-86 & $56 \pm 9$ & $83 \pm 5$ \\
-57 & $2 \pm 1$ & $6 \pm 1$ \\
pGL3 basic & 1 & 1 \\
SV40 & $60 \pm 3$ & $47 \pm 2$ \\
\hline
\end{tabular}

to contain the HSL gene [21], were used in Southern blot experiments. Products A and B hybridized to a $7 \mathrm{~kb}$ Bam HI fragment and a $6.2 \mathrm{~kb} E c o \mathrm{RI}$ fragment respectively. Sequencing of the genomic fragments revealed that the 5'-UTRs were contained in single exons. Genomic and cDNA sequences were identical. Exon A was located approx. $2.8 \mathrm{~kb}$ downstream of the testis-specific exon (exon T) and exon B was located $1508 \mathrm{bp}$ upstream of exon 1 (Figure 4). Consensus sequences for $5^{\prime}$ and $3^{\prime}$ splice junctions were found at the $3^{\prime}$ ends of exons A and B and at the $5^{\prime}$ end of exon 1, $20 \mathrm{nt}$ upstream of the translation initiation codon. 

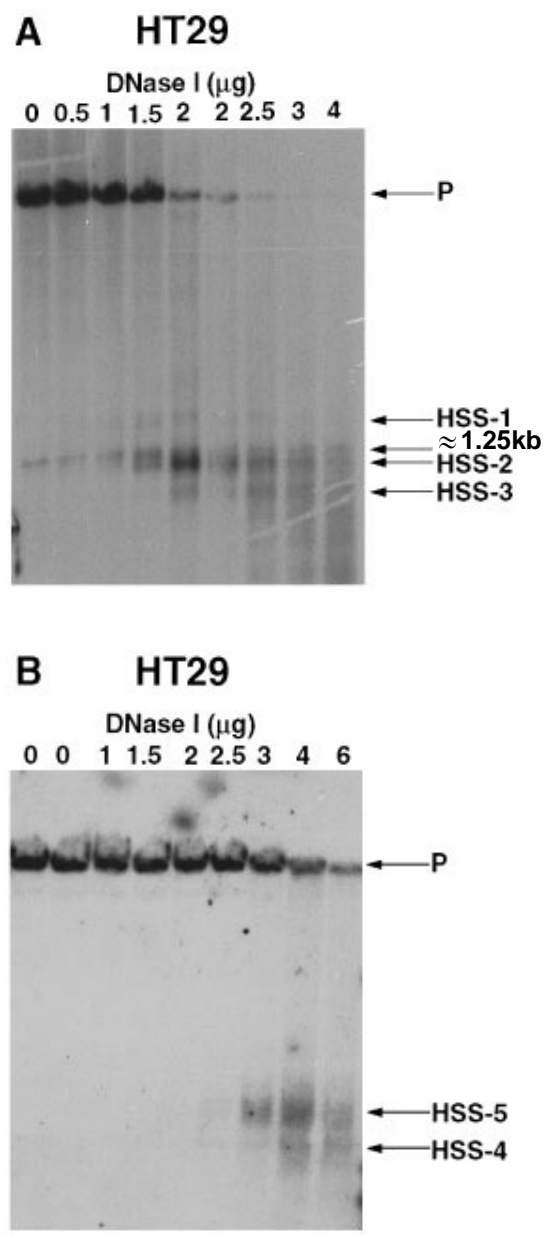

A $\quad$ Caco2

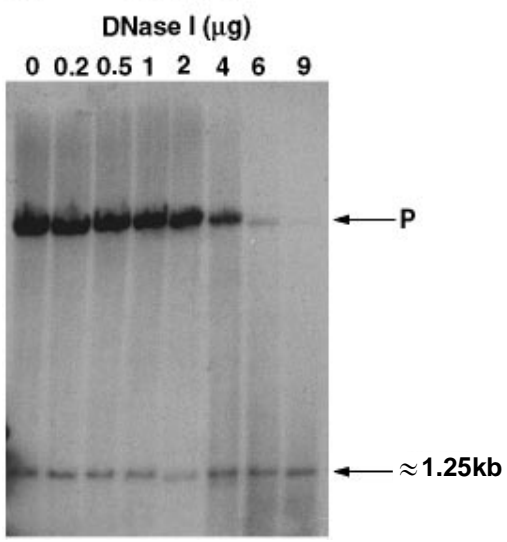

B $\quad$ Caco2

DNase I $(\mu \mathrm{g})$

$00.20 .5122406 \quad 9$

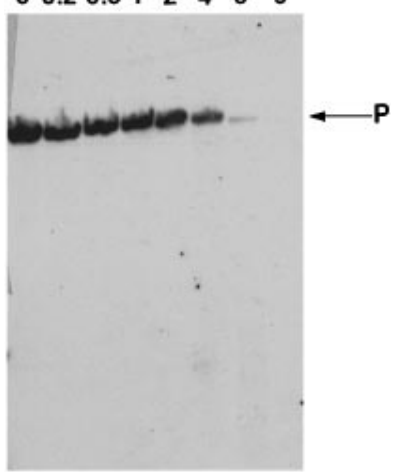

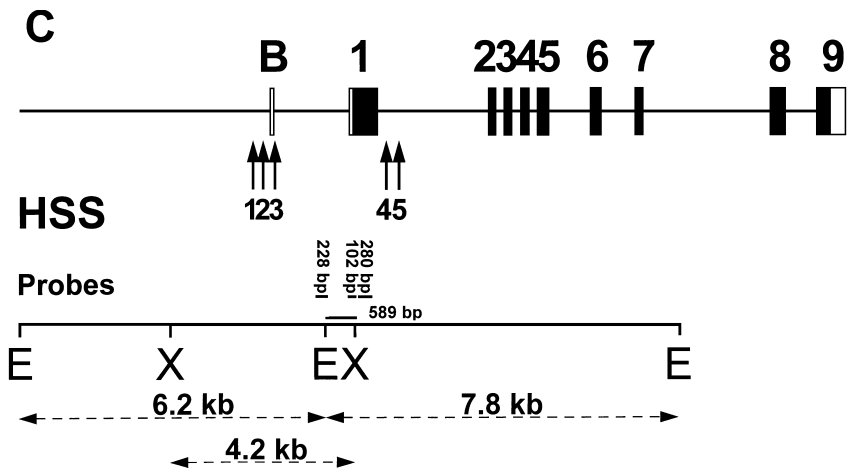

Figure 8 Localization of HSS associated with the human HSL gene

HT29 and Caco2 cell nuclei were digested with increasing amounts of DNase I as indicated. DNA isolated from DNase I-digested and undigested nuclei was digested with EcoRI, electrophoresed and transferred to nylon membrane as described in the Materials and methods section. The blot was hybridized with a 228 bp (A) or a 280 bp (B) ${ }^{32}$ P-labelled probe. The autoradiogram is representative of three independent experiments that gave similar results. P represents the parental band undigested by DNase I. (C) Restriction map (E, EcoRl; X, Xhol) and the localization of the probes and the HSS in the human HSL gene.

\section{Determination of the adipocyte-specific transcriptional start site}

Primer extension analysis with human adipocyte poly $(\mathrm{A})^{+}$RNA and an anti-sense oligonucleotide derived from the exon $\mathrm{B}$ sequence showed that the transcriptional start site was located 54 bp upstream of the $3^{\prime}$ splice site (Figure 5). The mapping was confirmed by Northern blot analyses of adipocyte total RNA with labelled oligonucleotides. Hybridization was seen with oligonucleotides derived from the exon B sequence but not with oligonucleotides derived from upstream genomic sequences (results not shown). Computer-based analysis [22] with the TSSG program (Baylor College of Medicine, Houston, TX, U.S.A.) of $2360 \mathrm{bp}$ upstream of the translation initiation codon predicted one promoter with a transcriptional start site corresponding 
exactly to the nucleotide determined in primer extension analysis (Figure 6). No CCAAT and TATA boxes were found. A GC box was found between -33 and $-38 \mathrm{bp}$.

\section{Deletion analysis of HSL promoter activity}

To test whether the 5'-flanking region upstream of exon B had promoter activity, a series of $5^{\prime}$ deletions within the first $2.4 \mathrm{~kb}$ were generated and ligated to the luciferase reporter gene. These deletions shared a common $3^{\prime}$ end at position +38 . Plasmids were transiently transfected into HT29 cells (Figure 7). The $-2400 \mathrm{nt}$ construct resulted in higher reporter gene activity than the SV40 promoter. High luciferase activity was observed for constructs containing the sequence between $n t-2400$ and -86 . A decrease in activity was observed between nt -2400 and -431, suggesting the presence of cis-acting elements in that region. 5'-Flanking regions in inverted orientations $(\mathrm{nt}+1000$ and +431 ) showed very low luciferase activities. Further deletion of sequences between nt -86 and -57 resulted in a marked decrease of luciferase activity, suggesting that cis-acting sequences beween $\mathrm{nt}-86$ and -57 were necessary for HSL promoter activity. To determine whether the promoter was active in an adipocyte cell context, plasmids were transiently transfected into rat adipocytes by electroporation [19]. High luciferase activity was found beween $n t-2400$ and -86 (Table $1)$. The nt -431 construct did not show lower activity than the other constructs. A similar pattern was observed in HeLa, a human cell line that does not express HSL. These results suggest that the molecular determinants of adipocyte specificity are not present in the $2400 \mathrm{bp}$ upstream of the transcriptional start site.

\section{Mapping of HSS}

To map HSS associated with the transcription of the human HSL gene, control and DNase I-treated nuclei were prepared from HT29 and Caco2, two human colon cancer cell lines that respectively express and do not express HSL. DNA was purified and digested with EcoRI or XhoI. After gel electrophoresis and transfer to nitrocellulose membrane, fragmented DNA was hybridized to various probes labelled by random priming. EcoRIdigested genomic DNA was first hybridized to a PCR-generated probe corresponding to the most $3^{\prime} 228 \mathrm{bp}$ of the $6.2 \mathrm{~kb} E c o \mathrm{RI}$ fragment (Figures 8A and 8C). This fragment contained exon $\mathrm{B}$ and its $5^{\prime}$ flanking sequence. In the absence of DNase I, two bands were detected in HT29 and Caco2 cells, the undigested EcoRI piece and a band of approx. $1.25 \mathrm{~kb}$. With increasing amounts of DNase I, three bands, named HSS-1, HSS-2 and HSS-3, were generated from HT29 nuclei. These bands were not detected in Caco2 nuclei. HSS-1, a weak but reproducible signal, was located approx. $1.5 \mathrm{~kb}$ upstream of the EcoRI site. HSS-2 and HSS-3 were located at approx. 1.2 and $0.9 \mathrm{~kb}$ respectively upstream of the EcoRI site. To confirm the presence of these HSS in HT29 cells and to determine whether the approx. $1.25 \mathrm{~kb}$ band was specific, genomic DNA was digested with XhoI, which yielded a $4.2 \mathrm{~kb}$ band in undigested nuclei and hybridized with a XhoI-StuI 102 bp probe located at the $3^{\prime}$ extremity of the XhoI fragment. The approx. $1.25 \mathrm{~kb}$ band was not detected in undigested nuclei. With increasing concentrations of DNase I, two bands were detected approx. $1.6 \mathrm{~kb}$ and $1.8 \mathrm{~kb}$ respectively upstream of the XhoI site that most probably correspond to HSS-2 and HSS-3 (results not shown). In experiments with Eco RI and XhoI, the HSS-2 band was more intense and appeared at lower DNase I concentrations than HSS-3. A $7.8 \mathrm{~kb}$ EcoRI fragment containing the first seven exons encoding the adipose form of HSL was also probed to locate hypersensitive sites (Figures 8B and 8C). First, a 589 bp EcoRI-XhoI piece was used as probe. It hybridized to multiple bands ranging from 3 to $20 \mathrm{~kb}$ on EcoRI-cut genomic DNA from nuclei not digested by DNase I (results not shown). Sequencing analysis revealed that this piece contained repetitive elements that are specific to this region of chromosome 19 [23]. A second probe corresponding to a $280 \mathrm{bp}$ AccI-Bst I fragment yielded two bands in HT29 cells but none in Caco 2 cells. These sites, named HSS-4 and HSS-5, were located downstream of exon 1, approx. 1.4 and $1.9 \mathrm{~kb}$ from the EcoRI site.

\section{DISCUSSION}

The present paper describes the first characterization of a human HSL promoter. We establish that the human HSL transcripts expressed in adipose tissue are $2.7-2.8 \mathrm{~kb}$ long and contain a single $5^{\prime}$-UTR of $74 \mathrm{nt}$. The first $54 \mathrm{nt}$ of this $5^{\prime}$-UTR are found, in the genomic sequence, in exon B located $1.5 \mathrm{~kb}$ upstream of exon 1 (Figure 4). In HT29 cells, two mutually exclusive 5'-UTRs are present in HSL transcripts. One corresponds to exon B and the other (exon A) was mapped in the genomic sequence approx. $2.8 \mathrm{~kb}$ downstream of the testis-specific exon. The $5^{\prime}$-flanking region of exon $\mathrm{B}$ functions as a strong promoter. Cell-typespecific HSS were found in the vicinity of the transcriptional start site of exon B and in the intron downstream of exon 1.

The human HSL gene shows a complex organization with the expression of at least three alternative $5^{\prime}$ termini in HSL transcripts. The exons containing the various $5^{\prime}$ ends are spread over a large genomic region because the distance from exon $\mathrm{T}$ to exon $\mathrm{B}$ is approx. $15 \mathrm{~kb}$, in contrast with the distance between exons 1 and 9 (approx. $11 \mathrm{~kb}$ ). An unusual feature of the HSL gene is the use of coding (exon T) and non-coding (exons A and B) $5^{\prime}$ alternative exons. Splicing of pre-mRNA sequences corresponding to these exons occurs at the same position in exon 1 , $20 \mathrm{nt}$ upstream of the translation initiation codon. Our results strongly suggest the use of alternative promoters in a tissuespecific way. Exon $\mathrm{T}$ is specific to the testis and not used in adipose tissue [6]. Exon B is used in adipocytes and HT29 cells but not in testis. A compilation of the results obtained with various techniques indicates that exon A-containing transcripts are found in significant amounts in HT29 cells and at very low levels in adipocytes. Furthermore the results show that the previously identified $5^{\prime}$-UTR of $632 \mathrm{nt}$ contiguous to exon 1 is not present to a significant extent in adipocytes. The possibility that the relative abundance of the various $5^{\prime}$-UTRs in human adipose tissue is subject to regulation cannot, however, be ruled out. A multiplicity of mRNA species with different $5^{\prime}$ termini has been shown for several genes. A good example is the $\gamma$ glutamyltransferase gene, which codes for six mRNA species from at least five different promoters [24,25]. The use of alternative promoters underlies the tissue specificity of expression in a number of genes such as the human aromatase cytochrome $P-450$ gene $[26,27]$.

This study provides the first functional characterization of a human HSL promoter; $5^{\prime}$ deletion constructs from nt -2400 to -86 showed high luciferase activity in two cell types expressing HSL, i.e. rat adipocytes and HT29 cells, and in HeLa cells, which do not express HSL. These results show that the first $2.4 \mathrm{~kb}$ of the 5 '-flanking region contain strong positive regulatory sequences. However, the sequences responsible for the tissue-specific expression of HSL are not present in this region because the pattern of promoter activity was similar in HeLa cells, adipocytes and HT29 cells. Adipose-specific enhancer can be located far upstream of the transcriptional start site as shown for the aP2 
fat-specific enhancer located between -4.9 and $-5.4 \mathrm{~kb}$ [28]. Deletion of HSL promoter sequences from nt -86 to -57 resulted in a marked decrease in luciferase activity. These results indicate that the 5 -end border of the minimal promoter is located between $\mathrm{nt}-86$ and -57 . This region contains a CAC sequence in a C-rich environment that could bind $\mathrm{Sp} 1$ and related transcription factors and participates in the trans-activation of the human HSL promoter [22,29]. An interesting feature of the promoter is the lack of consensus sequences for CAAT and TATA boxes. CAAT and TATA-less promoters initially described for housekeeping genes have now been shown for a number of genes with restricted tissue expression. Several features characterize this type of promoter. GC boxes are often present upstream of the transcriptional start site, which is true of the HSL promoter between $n t-33$ and -38 . Binding of Sp1 to the GC box seems in this context to be required for the stabilization of the initiation complex [30]. Moreover, in some TATA-less promoters, the TATA box is replaced by an $(\mathrm{A}+\mathrm{T})$ rich sequence that differs from the consensus TATA sequence but is nevertheless a functional promoter element. In the HSL promoter, the $(\mathrm{A}+\mathrm{T})$-rich sequence located between $\mathrm{nt}-22$ and -27 could have this role. Another feature of TATA-less promoters is the presence of an initiator element that encompasses the transcriptional start site. Analysis of DNA sequence requirements for transcriptional initiator activity revealed the approximate consensus sequence $\mathrm{YYCA}_{+1} \mathrm{NWYY} \mathrm{[31].} \mathrm{However,} \mathrm{the} \mathrm{cor-}$

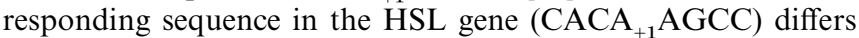
from the consensus sequence at positions -2 and +3 . This divergence apparently does not impair the promoter activity because the minimal promoter ( $-86 \mathrm{bp}$ construct) is as strong as the SV40 promoter (Figure 7 and Table 1). Moreover, unlike many TATA-less promoters that are characterized by numerous transcriptional start sites, a single transcriptional start site was detected in the HSL gene. This indicates that the proximal elements [e.g. the GC box, the $(\mathrm{A}+\mathrm{T})$-rich sequence and the initiator-like element] allow precise positioning of the RNA polymerase II complex.

DNase I HSS mapping is a convenient technique for scanning relatively large genomic regions for potential regulatory sequences. HSS sites are nucleosome-free regions that seem to be an essential feature of chromatin structure in eukaryotes [32]. The formation of HSS accompanies gene activation, and known regulatory elements reside within regions of DNase I hypersensitivity. Moreover, precise nucleosome positioning can facilitate or preclude the accessibility of cis-acting elements to trans-acting factors [20]. HSS-2 and HSS-3 are located in the vicinity of the human HSL gene minimal promoter (Figure 8C). These HSS were related to active gene transcription because they were not present in Caco 2 cells. HSS- 2 and HSS-3 could represent the binding sites of nuclear factors that participate in the formation and stabilization of the transcription initiation complex. The position of HSS-2 could correspond to the region between $n t-86$ and -57 that is necessary to drive high reporter gene activity. In agreement with an important role for that region, HSS-2 was more hypersensitive than the other HSS, regardless of the restriction enzyme used. These results are consistent with the binding of trans-acting factors essential for minimal promoter activity. Furthermore we analysed a region containing the first seven exons encoding adipocyte HSL. Two HSS sites were found in the intron downstream of exon 1 in HT29 cells but not in Caco 2 cells. The presence of these sites suggests the existence of enhancers linked to active HSL gene transcription. The presence of intronic HSS has been shown for a number of genes. Intronic HSS sites linked to gene expression have been characterized in fatty acid synthase, another key enzyme of lipid metabolism [33]. This site corresponds to a cisacting element that confers glucose responsiveness.

Through the precise mapping of the adipocyte-specific transcriptional start site, functional characterization of the minimal promoter and chromatin structure analysis, we provide a foundation for future studies aimed at understanding the transcriptional regulation of the human HSL gene and its tissuespecific expression in white adipocytes.

We thank Dr. Hélène Richard-Foy (IBCG-CNRS, Toulouse, France) for advice on HSS experiments, and Dr. Max Lafontan (INSERM U317, Toulouse, France) for a critical reading of the manuscript. The laboratories involved in this study are members of the European Union Concerted Action 'EUROLIP'. H.L. was supported by grants from the Swedish Institute and the Swedish Medical Research Council.

\section{REFERENCES}

1 Frayn, K. N., Coppack, S. W., Fielding, B. A. and Humphreys, S. M. (1995) Adv. Enzyme Regul. 35, 163-178

2 Langin, D., Holm, C. and Lafontan, M. (1996) Proc. Nutr. Soc. 55, 93-109

3 Holm, C., Belfrage, P. and Fredrikson, G. (1987) Biochem. Biophys. Res. Commun. 148, 99-105

4 Holm, C., Kirchgessner, T. G., Svensson, K. L., Fredrikson, G., Nilsson, S., Miller, C. G., Shively, J. E., Heinzmann, C., Sparkes, R. S., Mohandas, T. et al. (1988) Science 241, 1503-1506

5 Langin, D., Laurell, H., Stenson Holst, L., Belfrage, P. and Holm, C. (1993) Proc. Natl. Acad. Sci. U.S.A. 90, 4897-4901

6 Stenson Holst, L., Langin, D., Mulder, H., Laurell, H., Grober, J., Bergh, A., Mohrenweiser, H. W., Edgren, G. and Holm, C. (1996) Genomics 35, 441-447

7 Holm, C., Belfrage, P. and Fredrikson, G. (1989) Biochim. Biophys. Acta 1006, 193-197

8 Hellström, L., Langin, D., Reynisdottir, S., Dauzats, M. and Arner, P. (1996) Diabetologia 39, 921-928

9 Reynisdottir, S., Eriksson, M., Angelin, B. and Arner, P. (1995) J. Clin. Invest. 95 2161-2169

10 Stich, V., Harant, I., De Glizesinski, I., Crampes, F., Berlan, M., Kunesova, M., Hainer, V., Dauzats, M., Rivière, D., Garrigues, M. et al. (1996) J. Clin. Endocrinol. Metab. 82, 739-744

11 Berlin, I., Berlan, M., Crespo-Laumonnier, B., Landault, C., Payan, C., Puech, A. J. and Turpin, G. (1990) Clin. Sci. 78, 81-87

12 Schwartz, R. S., Jaeger, L. F., Veith, R. C. and Lakshminarayan, S. (1990) Int. J. Obesity 14, 1-11

13 Plée-Gauthier, E., Grober, J., Duplus, E., Langin, D. and Forest, C. (1996) Biochem. J. 318, 1057-1063

14 Remaury, A., Laurell, H., Grober, J., Reynisdottir, S., Dauzats, M., Holm, C. and Langin, D. (1995) Biochem. Biophys. Res. Commun. 207, 175-182

15 Chomczynski, P. and Sacchi, N. (1987) Anal. Biochem. 162, 156-159

16 Ausubel, F. M., Brent, R., Kingston, R. E., Moore, D. D., Seidman, J. G., Smith, J. A. and Strühl, K. (1996) Current Protocols in Molecular Biology, John Wiley and Sons, New York

17 Gautron, S., Maire, P., Hakim, V. and Kahn, A. (1991) Nucleic Acids Res. 19. 767-774

18 Tavernier, G., Galitzky, J., Valet, P., Remaury, A., Bouloumié, A., Lafontan, M. and Langin, D. (1995) Am. J. Physiol. 268, E1135-E1142

19 Rolland, V., Dugail, I., Le Liepvre, X. and Lavau, M. (1995) J. Biol. Chem. 270 $1102-1106$

20 Richard-Foy, H. and Hager, G. H. (1987) EMBO J. 6, 2321-2328

21 Laurell, H., Grober, J., Stenson Holst, L., Holm, C., Mohrenwieser, H. and Langin, D. (1995) Int. J. Obesity 19, 590-592

22 Bucher, P. (1990) J. Mol. Biol. 212, 563-578

23 Das, H. K., Jackson, C. L., Miller, D. A., Leff, T. and Breslow, J. L. (1987) J. Biol. Chem. 262, 4787-4793

24 Rajagopalan, S., Wan, D.-F., Habib, G. M., Sepulveda, A. R., McLeod, M. R., Lebovitz, R. M. and Lieberman, M. W. (1993) Proc. Natl. Acad. Sci. U.S.A. 90, 6179-6183

25 Sepulveda, A. R., Carter, B. Z., Habib, G. M., Lebovitz, R. M. and Lieberman, M. W. (1994) J. Biol. Chem. 269, 10699-10705

26 Harada, N., Utsumi, T. and Takagi, Y. (1993) Proc. Natl. Acad. Sci. U.S.A. 90, 11312-11316

27 Mahendroo, M. S., Mendelson, C. R. and Simpson, E. R. (1993) J. Biol. Chem. 268 19463-19470 
28 Ross, S. R., Graves, R. A., Greestein, A., Platt, K. A., Shyu, H.-L., Mellovitz, B. and Spiegelman, B. M. (1990) Proc. Natl. Acad. Sci. U.S.A. 87, 9590-9594

29 Boisclair, Y. R., Brown, A. L., Casola, S. and Rechler, M. M. (1993) J. Biol. Chem. 268, 24892-24901

30 Pugh, B. F. and Tjian, R. (1990) Cell 61, 1187-1197

Received 8 April 1997/1 July 1997; accepted 6 August 1997
31 Javahery, R., Khachi, A., Lo, K., Zenzie-Gregory, B. and Smale, S. (1994) Mol. Cell. Biol. 14, 116-127

32 Elgin, S. C. R. (1988) J. Biol. Chem. 263, 19259-19262

33 Foufelle, F., Lepetit, N., Bosc, D., Delzenne, N., Morin, J., Raymondjean, M. and Ferré, P. (1995) Biochem. J. 308, 521-527 